\title{
超音波併用脱灰処理骨の即時再植に関する実験的研究
}

\author{
弘中亮治・佐野和生・井口次夫
}

\section{Experimental studies on ultrasonic decalcification of bone implants}

\author{
Ryouji Hironaka - Kazuo Sano - Tsugio Inokuchi
}

\begin{abstract}
Decalcification of the bone implant has been performed to accelerate bone induction. Ultrasound applied to rapid decalcification was investigated for immediate reimplantation of the resected jaw bone.

Atomic absorption analysis of the amount of calcium dissolved into the solution of $0.6 \mathrm{~N}$ $\mathrm{HCl}$ from the bone subjected to decalcification revealed that ultrasonic application markedly shortened decalcification time.

Observation of ultrasonically decalcified bone matrix using scanning electron microscopy showed deeply perforated bone cavities and smoothly scrubbed bone surfaces, suggesting ultrasonic action to the bone in the decalcification solution.

Histological findings of decalcified bone matrix implanted in the abdominal wall muscles of rabbits indicated that ultrasonic decalcification preserves the bone induction property of the implant.
\end{abstract}

Key words: ultrasonic decalcification（超音波併用脱灰）, decalcified bone implantation（脱灰 骨移植), immediate reimplantation of bone (即時再植)

緒

\section{言}

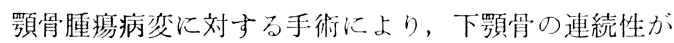
失われることが少なくない、その後の頡骨の再建のため に摘出自家骨の再植を行うことは, 解剖学的に最良の形 態を回復することができると同時に身体他部へ侵腤を加 えることがないため頃れた方法と思われる。しかしこ の場合摘出骨内の腫㿋細胞に対す万刹細胞処理が必要亡 なる1〜6)

一方，腫瘍手術，特に恶性腫瘍手術の場合には周四軟 組織の切除を伴うため，骨移植の日床としては良好な状 態とはい觉ない。したがって再植に際し，上記のような 殺細胞処理を行った移植骨片に，さらに脱灰処理を加党 ることによって骨誘学能を高めることは，良好な骨治捤 のために有意義なことと思われるマ

長崎大学附学部口腔外科学第 2 满座

(主任：井口次夫教授)

Second Department of Oral and Maxillofacial Surgery, Nagasaki University School of Dentistry (Chief: Prof. Tsugio Inokuchi)

受付日: 平成 2 年 8 月 29 日
脱灰骨の臨床応用に際して，脱灰による骨の機械的強 度の低下が問題となるが脱灰を表面にとどめることによ り，内部未脱灰部に上る機械的強度の保存と表面脱灰部 による骨誘導能の促准とが可能となる ${ }^{8 \sim 10)}$.この脱灰処 理を摘出自家骨の即時再植に応用するためには，脱灰処 理の迅速化が必要となる。

今回われわれは，病理組織標本の作製に応用されてい る超音波の併用による硬組織の脱灰促進作用に着目 し ${ }^{11 \sim 13)}$, 超音波併用塩酸脱灭法により作製した脱灰骨の 即時移植に関する基礎的检討を行った。

\section{方法}

\section{1. 脱灰骨の作製と観察}

10週桻メスの家象より摘出した上腕骨，前腕骨，一腿 骨，敃よび脛骨の骨髄扎よび周囲軟組織を除去したの ち, 約 $12 \times 10 \mathrm{~mm}$ の骨片とした. Urist らの方法 $5,9,14$, および Reddi らの方法 ${ }^{15,16)}$ をもとに計画したスケシュ ールに徉って以下の処理を行った. 上昇アルコール(70, $80,90,100 \%$ ) にて脱水, $100 \%$ エーテルにて脱脂した 後, 骨 $1 \mathrm{~g}$ 当り 0.6 規定塩酸 $200 \mathrm{ml}$ を用いて脱灰した。 脱灰に際し，超音波を併用したものを超音波侀用脱伙 


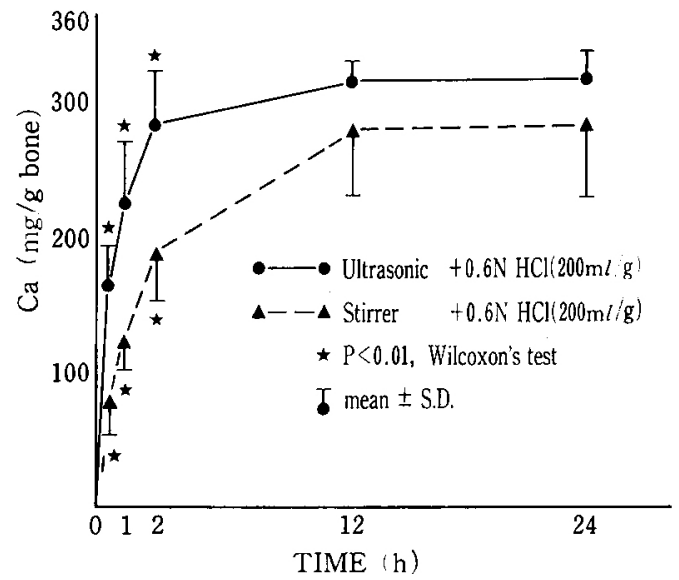

図 1 家鬼長管骨脱灰时のC $\mathrm{a}$ 溶出量

群，また，超音波を使用せずスターラーによる塩酸の䚓 扭のみを行ったものを対照群とした，脱网液中へのカル シウム溶出量を脱灰開始後 30 分，1，2，12，24時間に 括いて, 原子吸光法 (日立原子吸光測定器偏光ゼーマン 180-80型)により測定した。

また，脱灰処理による骨の経時的変化を軟エックス線 写真, コンタクトマイクロラジオグラフィー，走查電子 影微鏡により権察した。

超音波発生装置は，ブランソン社製超音波洗浄装置ブ ランソニック 221 型 $(47,000 \mathrm{~Hz})$ を用い，超音波による 温度上昇を制御するため流水による還流を行って脱灰液 温を $18 ー 22^{\circ} \mathrm{C}$ に維持した、スターラーによる摫汼時の 液㴜は $18 〜 20 \mathrm{C}$ であった。

\section{2. 家鬼腹直筋下移植実験}

上記の方法により作製した超音波併用脱灰群と，対照 群のおの括の $1 ， 2 ， 12 ， 24$ 時間脱灰処理骨を，70\%アル コール洗浄につづき，生理食塩水による洗浄後，10週㱓 メスの家鬼腹直筋下に移植した。 $1,2,4,6,8,10$,

12，14週後に屠殺し，移植骨を周囲軟組織を含めて摘出

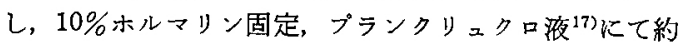
100 時間脱灰後，通法によりパラフィン切片を作製し， Hematoxylin-Eosin 染色を行った。

\section{結}

果

\section{1.脱灰骨の作製と観察}

1) 家鬼長管骨脱灰時のC'a溶出量

脱灰液吃の $\mathrm{Ca}$ 溶出量を测定し，その溶出曲線を示 した(図1).

超音波併用脱灰群の 1 時間值 $224 \mathrm{mg}$ に対し，対照群 では $117 \mathrm{mg}$ を示した。兩群ともその後 2 時間まで溶出

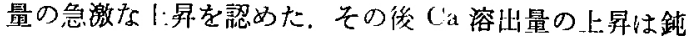
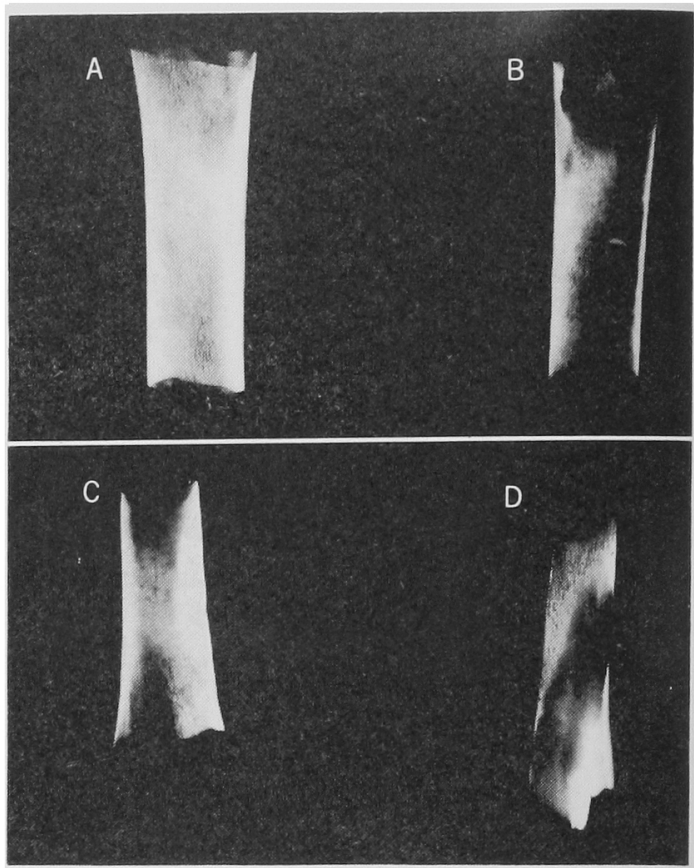

写真 1 家鬼長管骨脱灰処理後の軟エックス線写真
A ・スターラー垪用 1 時間眖灰骨
B . スターラー併用 2 時間脱灰骨
C：超音波併用 1 時間脱灰骨
D：超音波併用 2 時䦭脱灰骨

化し，12 時間以後ではほぽプラトーとなった。すなわ ち, $\mathrm{Ca}$ の溶出は0〜2 時間にピークがあると思われた。 超音波併用脱灭群と対照群の間には30分檤，1時間値， 2 時間值に执いて, 統計学的有意差 (Wilcoxon 椧定, $\mathrm{P}<0.01)$ を認めた.

2）脱灰処理骨の軟エックス線写真所見

脱灰処理開始後の軟エックス線写真では両群とも経時 的なエックス線透過性の上昇がみられた，特に 12 時間 後，24㭙間後の脱灰骨では著明な脱灰の進行を認めた， また， 1 時間，2 時間脱灰骨では，部分的な蹯状構造が 多くみられたが，形態的には脱灰の程度，扣よび様相に おいて, 超音波併用群，対照群間の差違は認められなか った. 写真には 1 時間， 2 時間脱扊後の軟エックス線像 を示す（写真１).

3) 脱灰処正!骨のコンタクトマイクロラジオグラフィ - (以下 CMR と略す)

超音波併用 1 時間脱灰骨の N NR では，中央の未脱 灰部と，顆粒状の末脱灰部を含む表層の脱灭部が観察さ れた（写真 2).

4) 脱灰処理骨・の走查電㩆所見

沫処理骨では全体的に粗造な面を呈し，裴面には顆粒 状物が多数存在し，小孔の散任が認められた（写真了）. 


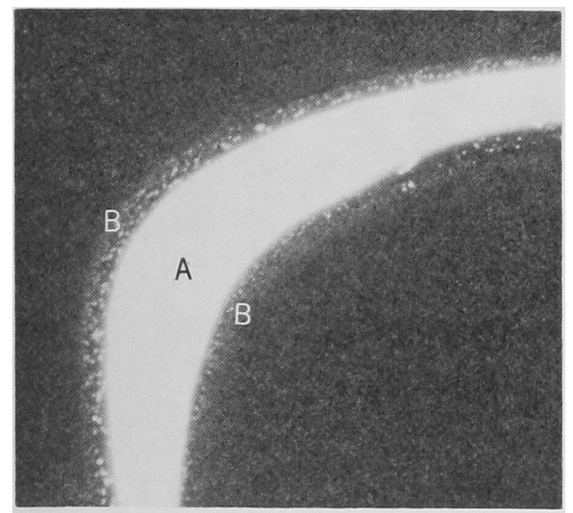

写真 2 超音波併用 1 時間脱灰骨の CMR 像
$\mathrm{A}$ : 未脱灰部
$\mathrm{B} ：$ 顆粒状の未脱灰部を含む表層脱灰部

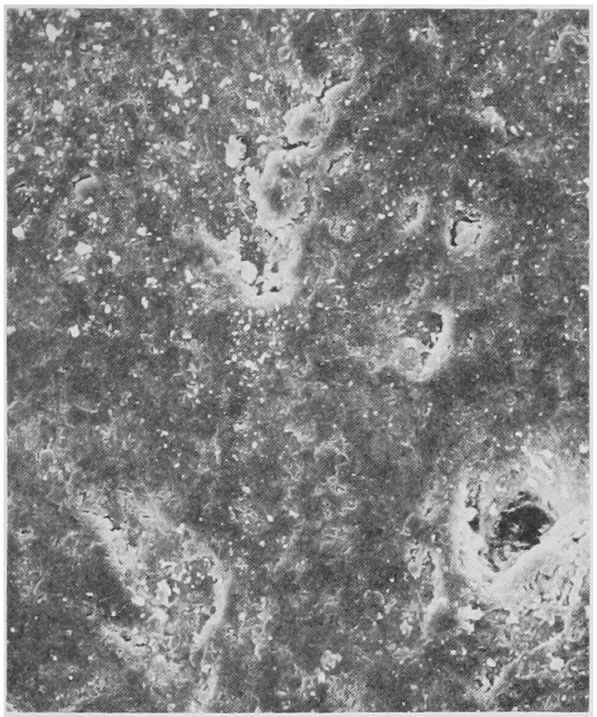

写真 3 走查電顕像 未処理骨 $(\times 500)$

超音波併用 1 時間脱灰骨では, 表面は平滑で小顆粒状 物質が点在している，小孔辺縁では数層に及ぶ買板状の 構造がみられ，小孔深部に拈ける空洞の拡大が認められ た（写真 4 ).

対照群 1 時間脱灭骨では，全体に小孔の数が増加し小 孔のみられない部分では平滑化が，小孔の周辺部では微 細な梁状構造が認められた（写真 5 ).

超音波併用24時間脱灰骨では表面は滑らかで，小孔深 部にいたる空洞への移行も滑らかであった（写真6）.

対照群24時間脱兏骨では鋭い辺縁を有する大小の付着 物が重積しているような凹凹不整の面観を呈していた (写真 7 ).

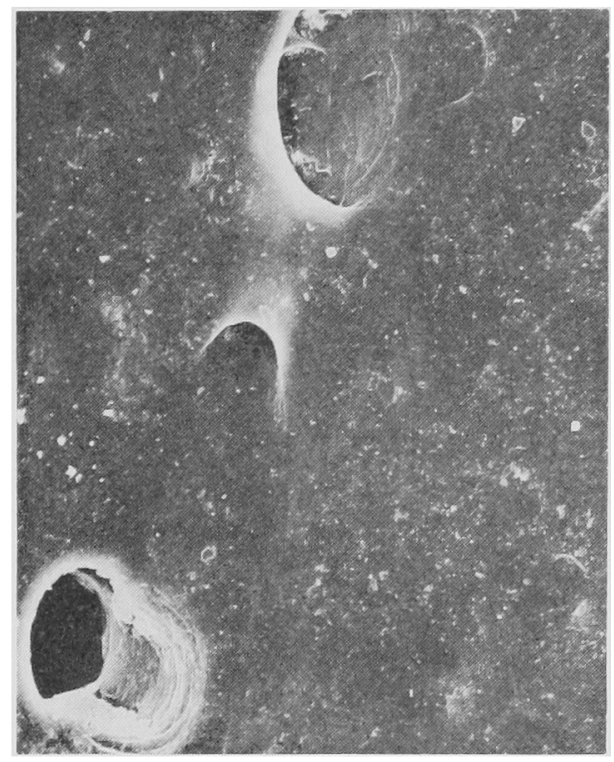

写真 4 走查電影像

超音波併用 1 時間脱戻骨 $(\times 500)$

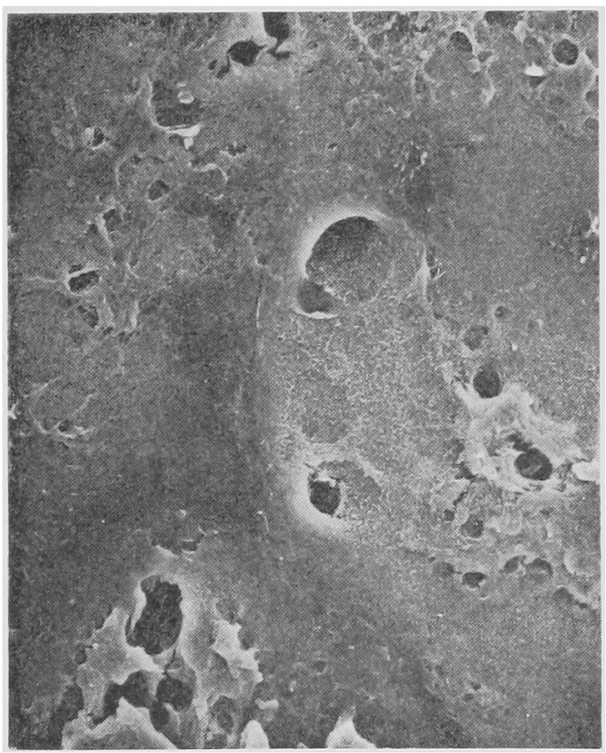

写真 5 走査電顕像

スターラー併用 1 時間脱灰骨 ( × 500)

\section{2. 家兔腹直筋下脱灰骨移植実験}

術後 1，2 週では超音波併用脱灰群と対照群の相違は ほとんどみられなかった，術後 1 週では，移植骨の骨小 貯にはほとんど細胞を認めず空洞化しており，移植骨と 隣接する紡錘形の線維細胞扣よび骨周团に組織球, 線維 芽細胞などを認め，また軽度の炎症性細胞浸潤が認めら 


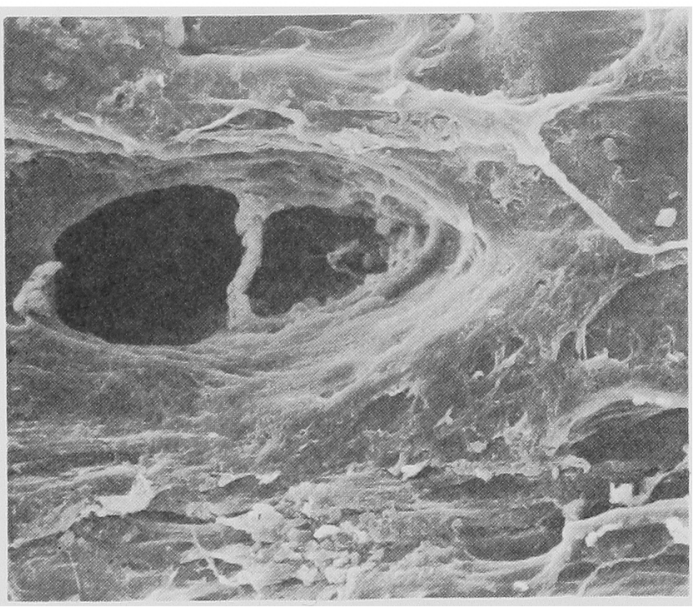

写真 6 走査電影像 超音波併用24㭙間脱灰骨 $(\times 500)$

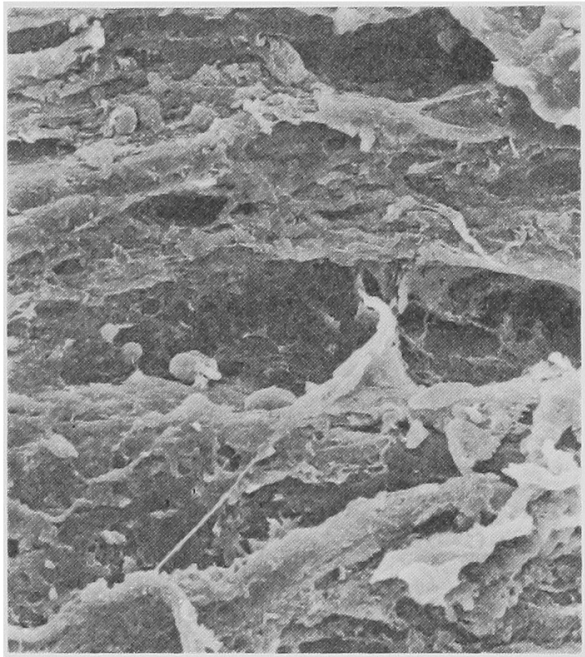

写真 7 走查電顕像

スターラー併用 24 時間脱灰骨 $(\times 500)$

れた（写真 8,9 ).

術後 2 週では周团軟組織中に異物巨細胞を認めた（写 真10).

術後 4 週では, 両群に㧊いて移植骨基質の空胞は残存 しているが，骨細胞を有する新生骨の增生がみられ，そ の周囲には骨芽細胞頑似の細胞の柵状配列ととも《破骨 細胞を認めた。 また，新生血管の拡張がみられた（写真 $11,12)$.

超音波併用 2 時間脱灰群, 対照群 2 時間脱灰群とも K, 1 時間脱灰群と同様の所見に加之骨䯣を思わせる線 維性結合組織を認めた（写真13，14）。

術後 8 週の超音波併用 1 時間脱灰群では新生骨, 幼若

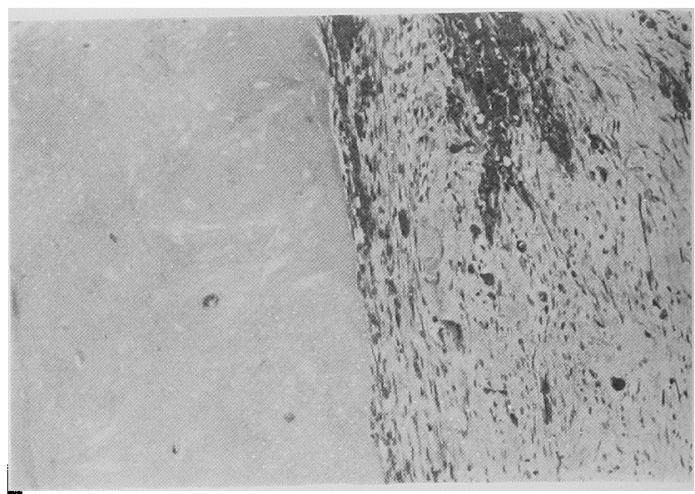

写真 8 移植 1 週後の組織像 超音波併用 1 時間脱灭骨 $(\times 20)$

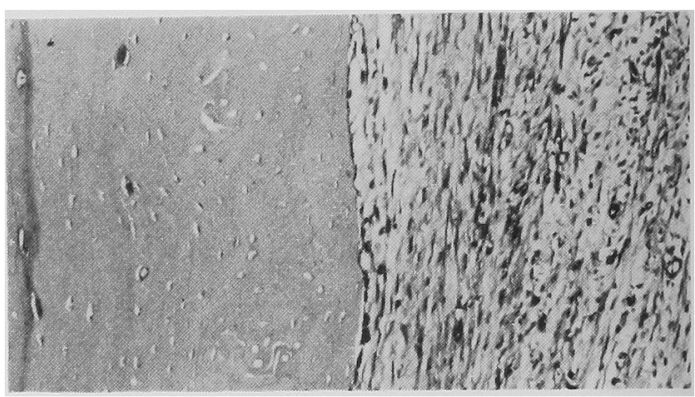

写真 9 移植 1 週後の組織像 スターラー㐿用 1 時間脱灰骨 $(\times 20)$

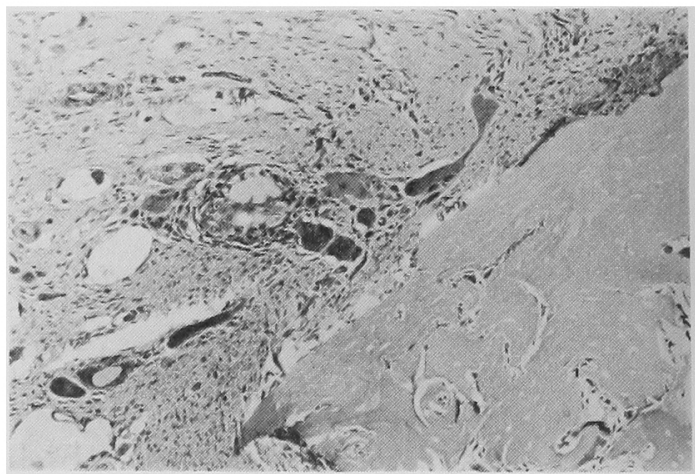

写真 10 移植 2 週後の組繊像

超音波併用 1 時間脱灰骨 $(\times 20)$

な血管，骨芽細胞の棚状配列，骨郘道様組織を認めるもの の赤色骨䯣にはいたっていないと思われた（写真15）. 対照群 1 時間脱灰群では上記の所見に加兄て細胞成分似 富九た赤色骨䯙の形成を認めた（写直16).

超音波併用 2 時間脱灰群, 対照群 2 時間脱灰群では, 成熟した骨檤像を呈していた（写直17，18）。

術後10週では，両群に扣いて赤色骨髄と脂肪組織の豊 


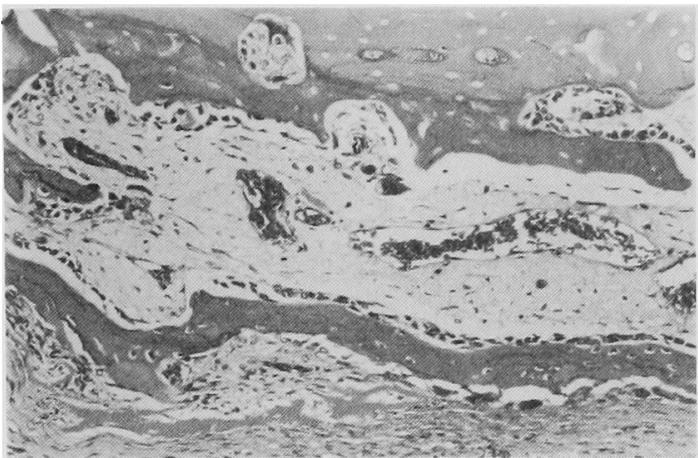

写真 11 移植 4 週後の組織像

超音波併用 1 特間脱灰骨 $(\times 50)$

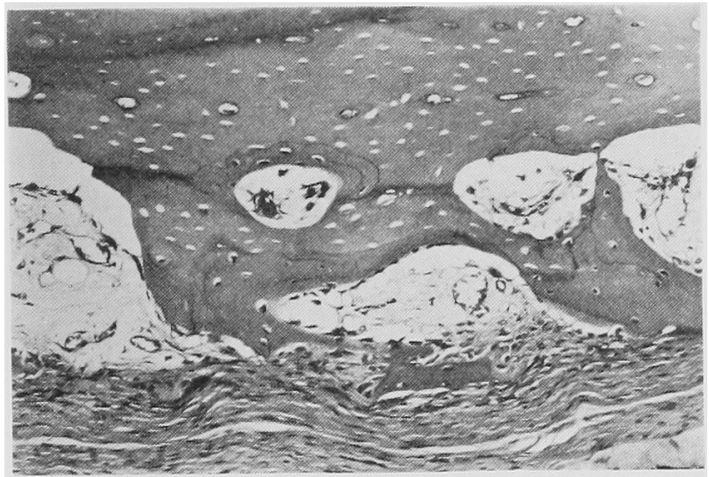

写真 12 移植 4 週後の組織像

スターラー併用 1 時間脱灰骨 $(\times 50)$

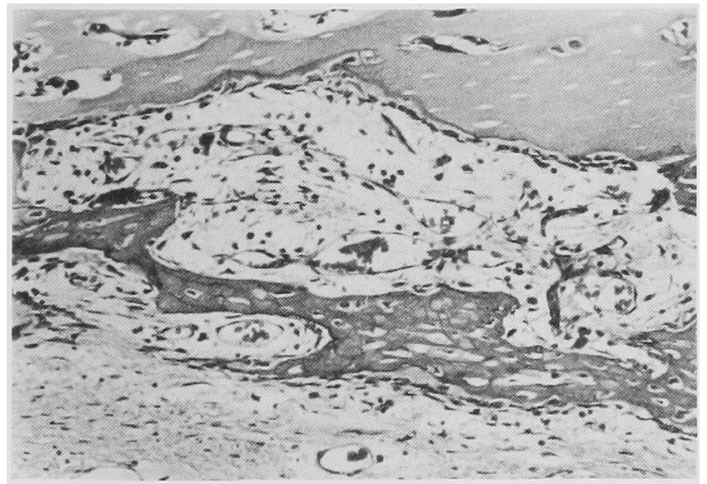

写真 13 移植 4 週後の組織像

超音波併用 2 時間脱灰骨 $(\times 50)$

富な黄色骨䯣の混在がみられ，術後14週では，両群とも 広沉な黄色骨䯣と少量の移植残存骨，新生層板骨を認め た（军真19，20）.

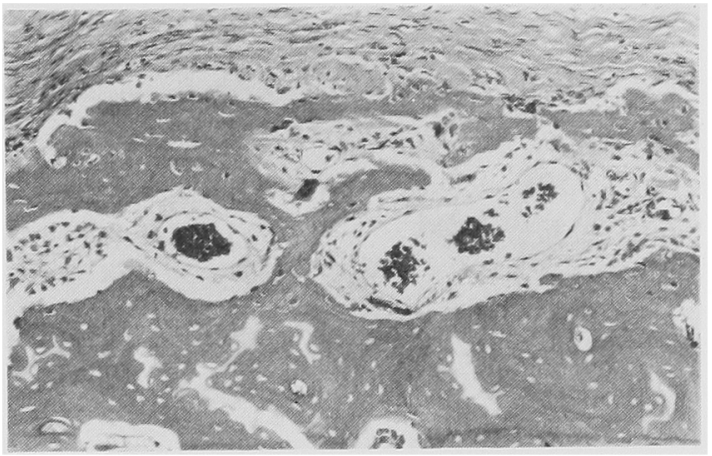

写真 14 移植 4 週後の組織像

スターラー併用 2 時間脱灰骨 $(\times 50)$

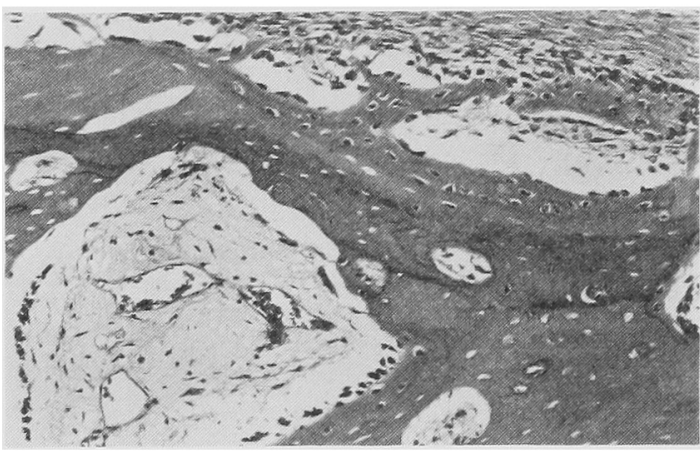

写真 15 移植 8 週後の組織像

超音波併用 1 時間脱灰骨 $(\times 50)$

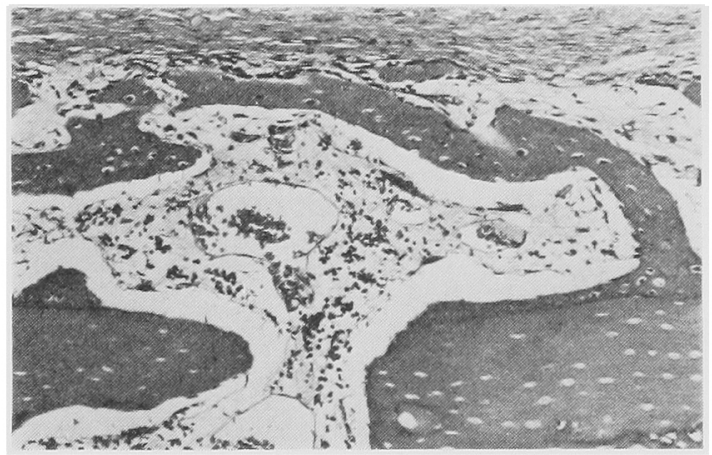

写真 16 移植 8 週後の組像

スターラー併用 1 時間脱灰骨 $(\times 50)$

考

察

\section{1. 超音波併用脱灭骨の作製}

超音波発生装置を病理組織標本作製時の脱灰処理に応

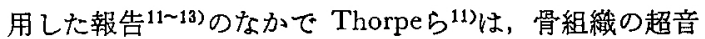




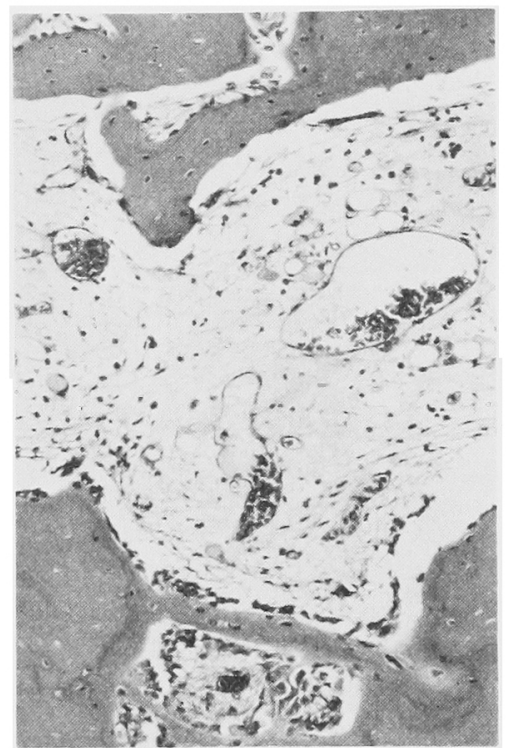

写直 17 移植 8 週後の組織像 超音波垪用 2 時間脱灰骨 $(\times 50)$

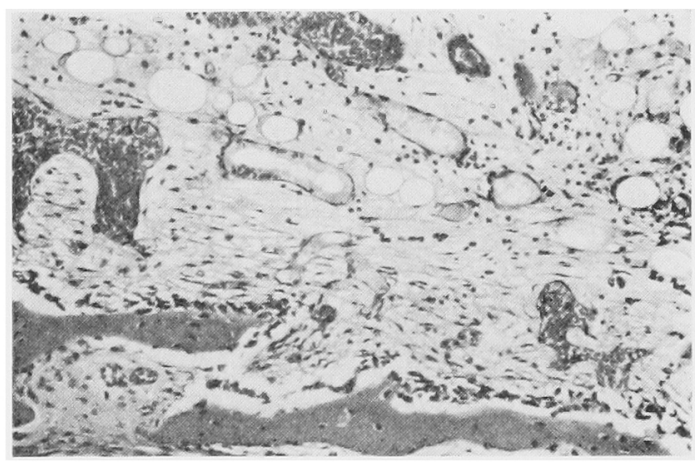

写真 18 移植 8 週後の組織像 スターラー垪用 2 時間脱灰骨 $(\times 50)$

波併用脱灭処理を液温 $56^{\circ} \mathrm{C}$ で行い，脱灰時間が $1 / 6$ $1 / 10$ に短縮したと述べている，本実験です眖灰液への Ca 溶出量の経時的測定に拈いて，超音波併用に上る脱 灰時間の藷明な短縮が認められた。

Morris $5^{12}$ 《脱灰液霓汼の效果として，1．脱灰表面 の気泡の集皘の防止，2，骨から溶出した 無機質の骨周 囲での停膟の防止，3．脱灰液の均等化をあげている。 超音波の店用は上記に加えてキャビテーション11)の発少: と破懐による衝整の関与により，学表面のかきとり現 象，骨小孔部での深達性が得られる。また，軟組織では 衝暂の吸収により超音波の影響は小さいと考えられてい る。本実験に和ける，超音波阙用脱灰骨の走查電顕像で の超音波による脱灰液の深達性を示唆する所見就よび，

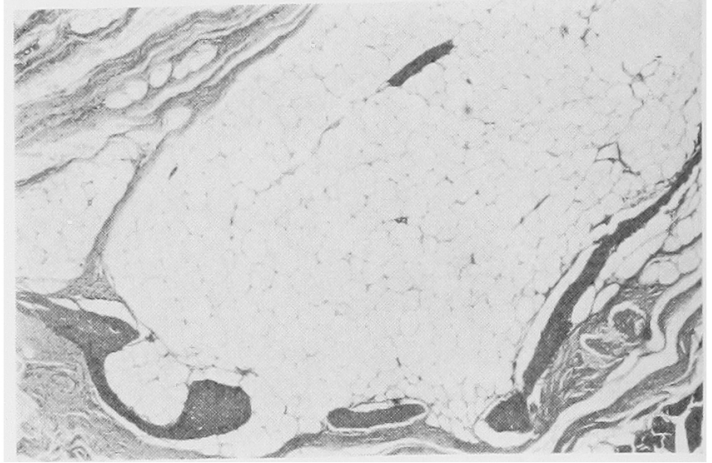

写真 19 移植 14 週後の組織像 超音波併用 1 時間脱灰骨 $(\times 10)$

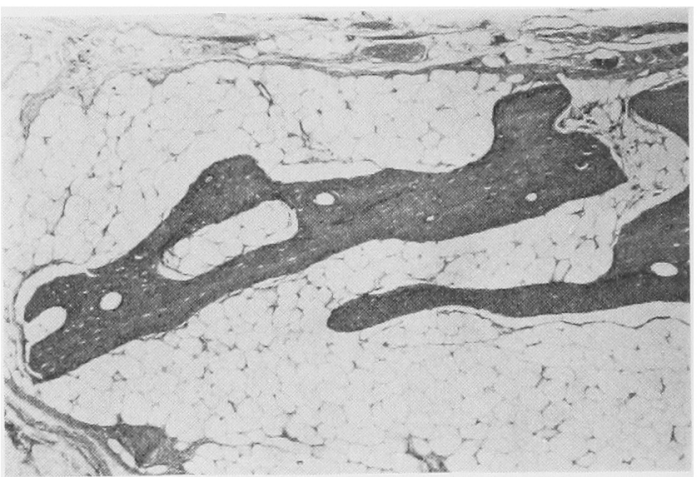

写真 20 移植 14 週後の組織像

スターラー竍用 1 時間脱兏骨 $(\times 10)$

骨表面の成分の剩離を示す所見は超音波作用に上る脱灰 時間の短縮を裏づけるものと考えられる。

\section{2. 家鬼脱灰骨移植}

移植後の経時的組織变化では，超音波併用群，スター ラー併用群ともに，1週間後に炎症性細胞浸潤，線維芽 細胞，2週間後に異物巨細咆，4週間後に部分的な移植 骨の吸収と骨新生，8週間後に赤色骨政形成，10週間後 に黄色骨髄化を認めた。

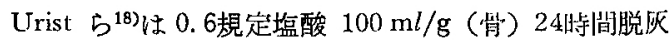
および凍結敞燥処理を行った家鬼長管骨の移植後の経時 的組織変化について報告しているが，本実験での超音波 併用脱灰群と対照群も，ほぼ同様の経時的組織变化を示 した。

Urist ら ${ }^{18)}$ は超音波処理により兴組織は著しく縮小す ると述べている，さらに悲波甠用脱灰骨移植例に执い ては，骨誘導能がみられたのは50\%に過ぎず，またその 骨誘導能も著しく減少していたと報告している。これに 対し，本実験の組織学的所見では超音波任用眖灭群とほ ぼ同様の良好な骨形成を認めた。

舶言で述べたように脱灰骨の臨床応用に際して，脱灰 
に上る機械的强度の低下が問題となるが表而脱炏処珄

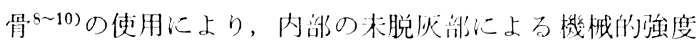
の保存と表面の脱灭部による骨誘筫能の促進が可能とな り，以上の問題点は解決できる。本拣駼で作製した超音 波併用 1 時間脱灭骨は（MR の観察結果より表面の脱 灭部と内部の未脱灭部とを諰め，表面脱灭処理骨である ことが確滺された。

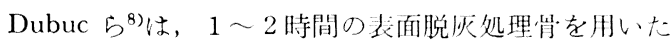

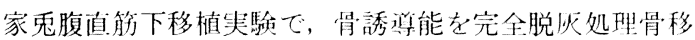
植例と比較した結果，表面脱灭処理骨移植例は完全脱灰 処理骨移植例とほぼ同等な良好な骨誘導能を示したと述

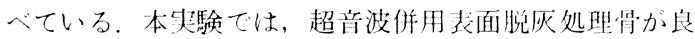
好な骨誘導能を有していること孝組織学的に確認するこ とができた。

以上より即時再植を目的とする超音波俾用による讯速 骨脱灰法の有用性が示された。

\section{結語}

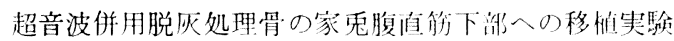
を行い，以下の結果を得た。

1. 超音波の僧用により，骨の脱灰時䦗を短維与るこ とが可能となった。

2. 家鬼腹直筋下脱灰骨移植に求いて，超省波併用脱 灭群はスターラー脌用脱灭碓と同様な骨誘萑能を示し た。

3. 即時骨再梢に際して，骨の表而脱厕処理に超音波 を併用することは，脱忦时間を短縮できる点で有用であ ると思犼た。

本矿究の一部は, 第50回日本几腔外科学会儿州地方部 会に扣いて発表した。（文部省科学研究莎第61771685 号 によった）

原子吸光法に閶し，種々御教示いただいた本学:附科薬 理学諈座加藤有三教授招よび教宝員の皆栚に感謝いたし ます。

\section{引用文 献}

1) Weaver, A.ll: and Smith, D.B.: Frozen autogenous mandibular stent-graft for immediate reconstruction in oral cancer surgery. Am J Surg 126: 505-506 1973.

2) Marciani, R.D. and Bowden, C.M.: Reimplantation of frecze-treated mandibular bone. J Oral Surg 33: 261-267 1975.
3) ('ummings, C.W.: Experimental observation of canine mandibular regeneration following segmental removal, freezing, and reimplantation. Ann Otol Rhinol Laryngol (Suppl 54) 87: 1-11 1978 .

4) 小村 健, 武宮三三：煮沸骨再植に上る下䍝骨 再建。 日只外誌 30：1360-1368 1984.

5) Rolf, E. and Konrad, W: : The autoclaved autogenous reimplant, an immediately replaced, mineral frame. J Max-Fac Surg 14: 1381421986.

6) Konrad, W. and Rolf, E.: The autoclaved autogenous bone graft as a reimplant. J MaxFac Surg 14: 132-137 1986.

7) Urist, M.R.: Bone formation by autoinduction. Science 150: 893-899 1965.

8) Dubuc, F.L. and Urist, M.R.: The accesivility of the bone induction principle in surfacedecalcified bone implants. Clin Orth and Related Research 55: 217-223 1967.

9) Urist, M.R. . Surface-decalcified allogeneic bone (SDAB) implants. Clin Orth and Related Research 56: 37-50 1968.

10) Jones, J.C., Lilly, G.E., et al.: Mandibular bone grafts with surface decalcified bone. J Oral Surg 30: 269-276 1972.

11) Thorpe, E.J., Bellomy, B.B., et al.: Ultrasonic decalcification of bone. J Bone and Joint Surg 45: 1257-1259 1963.

12) Morris, R.E. and Benton, R.S.: Studies on demineralization of bone. Am J Clin Path 26: 579-595 1956.

13) Poston, F.: Bone decalcification expedited by ultra sound. Am J Med Technol 33: 2632681967.

14) Urist, M.R., Dowell, T.A., et al.: Inductive substrates for bone formation. Clin Orth and Related Research 56: 59-96 1968.

15) Reddi, A.H. and Huggins, C.B.: Biochemical sequences in the transformation of normal fibroblasts in adolescent rats. Proc Nat Acad Sci USA 69: 1601-1605 1972.

16) Reddi, A.H. and Huggins, C.B.. Influence of geometry of transplanted tooth and bone on Iransformation of fibroblasts. Proc Soc Exp Biol Med 143: 634-637 1973.

17) 日本病理学会編：病理組織標本作製技術。上巻, 医橉薬计版，東宗，1982，54-59頁。

18) Urist, M.R., Silverman, B.F., et al.: The bone inductive principle. Clin Orth and Related Research 53: 243-283 1967. 